\title{
Phaeomarasmius confragosus - an agaric to be transferred to Tubaria
}

\author{
HARRI HARMAJA
}

\begin{abstract}
HARMAJA, H. 1978: Phaeomarasmius confragosus - an agaric to be transferred to Tubaria. - Karstenia 18: 55-56.

It is confirmed that Phaeomarasmius confragosus (Fr.) Sing. should be included in the genus Tubaria (W.G. Smith) Gill. The new combination Tubaria confragosa (Fr.) Harmaja is made. In both $T$. furfuracea ( $\mathrm{Fr}$.) Gill. and $T$. confragosa, the walls of the spores and basidia are reported cyanophilic and the spores binucleate.
\end{abstract}

Harri Harmaja, Botanical Museum, University of Helsinki, Unioninkatu 44, SF00170 Helsinki 17, Finland

Tubaria confragosa (Fr.) Harmaja, n. comb. - Agaricus confragosus Fries, Epicrisis Systematis mycologici...: 169. 1836-1838. - Pholiota confragosa (Fr.) Karst., Bidr. Känned. Finlands Nat. Folk 32: 304. 1879. - Naucoria confragosa (Fr.) Sing., Beih. Bot. Centralbl. 56(B): 00. 1936. - Phaeomarasmius confragosus (Fr.) Sing., Sydowia 15: 75. 1962. [ - Tubaria confragosa (Fr.) Kühn., Trav. Labor. La Jaysinia 3: 71. 1969. - Combination illegitimate as being not published validly: reference to publication of the basionym is lacking (Int. Code of Bot. Nomenclature, Art. 33)]

Many authors of modern taxonomic studies on the Agaricales (e.g. Singer 1975) have assigned Agaricus confragosus Fr. to Phaeomarasmius Scherffel as $P$. confragosus (Fr.) Sing. However, for years I have been struck by the similarity in macroscopic appearance between $P$. confragosus, a species occurring here and there in different parts of Finland, and the species of Tubaria (W.G. Smith) Gill., especially the larger ones. The features shared are the fairly similar colour of the basidiocarp, which is brown throughout, the hygrophanous pileus, the broadly adnate to short-decurrent lamellae, the striking pure white basal tomentum (with a few mycelial hairs at times), the tendency to grow on wood substrates, and the brownish spore deposit (though of different shades). In particular, my attention was caught by the conspicuous cottony basal tomentum, whose pure white colour stands out strongly between the more or less brown colours of the stipe and the adhering substrate. This pure white, fairly abundant tomentum has never been emphasized in the literature as a feature of $P$. confragosus or Tubaria spp., but it is in fact a character assisting in the macroscopic identification of the genus Tubaria.

The genus Phaeomarasmius, with $P$. confragosus, has been kept separate from Tubaria mainly on the basis of a difference claimed to exist in the structure of the pileus cortex: Tubaria is said to possess an epicutis of fairly narrow thin-walled hyphae and Phaeomarasmius a more or less palisade-like trichoderm with thickened hyphal walls. The spore deposit of Tubaria is without doubt paler brown than that of Phaeomarasmius. However, $P$. confragosus has always been considered a deviating component in Phaeomarasmius.

I examined the generic position of $A$. confragosus by comparing the structure of the pileus cortex and the responses of the hymenial elements to Melzer's reagent, heated cotton blue, and heated acetocarmine in that species and in the type species of Tubaria, $T$. furfuracea (Fr.) Gill. The specimens examined were collected from Finland and are: $P$. confragosus, Etelä-Häme, Lammi, 5.IX.1973 Tuomikoski (H); T. furfuracea, Uusimaa, Hanko, Tvärminne, 24.VI.1952 Tuomikoski (H).

The structure of the pileus cortex did not reveal any qualitative differences between the species, and even the quantitative ones were slight. T. furfuracea has a cutis with a tendency towards a trichoderm, $P$. confragosus possesses a cortex intermediate between a cutis and a trichoderm; in both the walls of the projecting hyphal ends are apt to be slightly thickened. In $P$. confragosus the cells in both the horizontal and ascending hyphae are shorter, somewhat more inflated, and with slightly thicker 
walls (commonly up to $1.5 \mu \mathrm{m}$ ) than in $T$. furfuracea, but the wall thickness occasionally reaches $1.5 \mu \mathrm{m}$ in T. furfuracea also. There is no differentiated subcutis or hypoderm in either of the species.

In Melzer's reagent no amyloid or dextrinoid reactions were observed in the pileus hyphae or hymenial elements, including the spores. The cystidia are of the same kind in both species. Clamp connections are present in both.

In both species, cotton blue provoked a weakly to moderately cyanophilic response in the spore walls and a moderately cyanophilic one in the hilar appendages of the spores. Cyanophily is uncommon in the mature spore walls of the dark-spored Agaricales. In both species the spore walls lack a germ-pore and callus. The basidial walls proved to be very weakly cyanophilic in both cases, whereas the walls of the cystidia were cyanophobic in both.

Acetocarmine stained only the nuclei in both species. The walls and hilar appendages of their spores, and the walls of the basidia and cystidia proved carminophobic at all stages of development. The basidia did not contain carminophilic granules. The spores were binucleate in both species.

In summary, the characters examined above did not reveal distinct differences between the two species. Consequently, according to present knowledge, $P$. confragosus differs from all (or most of?) the Tubaria species in two respects only: its spore colour is slightly darker brown and its velum forms a persistent distinct membranous annulus on the stipe. In view of the numerous important similarities now known to exist between $P$. confragosus and Tubaria spp., these differences are best considered infrageneric, and consequently $P$. confragosus should be transferred to the genus Tubaria.

Kühner (1969) came to the same conclusion, chiefly on the basis of the fairly similar general appearance of the basidiocarps of $P$. confragosus and Tubaria spp. and the lack of pronounced differences in their pileus cortices. However, he did not emphasize the adnate lamellae and white basal tomentum of $P$. confragosus, nor did he examine responses to cotton blue or acetocarmine. Anyway, Kühner presents a thorough description of $P$. confragosus, which includes the characters of the mycelium in culture.

\section{References}

Kühner, R. 1969: Une Agaricale peu connue: Tubaria confragosa (Fr.) comb. nov. - Trav. Labor. La Jaysinia 3: 67-71.

Singer, R. 1975: The Agaricales in modern taxonomy. Ed. 3. - 912 pp., 84 pls. Vaduz.

Accepted for publication

on July 28,1977 